\title{
e-interview
}

columns

\section{Driss Moussaoui}

Driss Moussaoui is Professor and Chairman, Department of Psychiatry, Ibn Rushd University Psychiatric Centre, Casablanca, Morocco, and Director of a World Health Organization (WHO) Collaborating Centre in Mental Health. He is President-Elect of the World Association for Social Psychiatry (WASP) and a member of the French Academy of Medicine. He trained at Rabat University and Sainte-Anne Hospital in Paris. His special interests include transcultural psychiatry.

If you were not a psychiatrist, what would you do?

I would probably be a historian. One of the greatest pleasures I have is to isolate myself with a good book on history. I could also have been a movie director. In common with psychiatry is the extraordinary diversity of the human condition which is considered in cinema.

What has been the greatest impact of your profession on you personally? To be a little more at ease with the complexity of human beings, including with myself. The psychoanalysis sessions I had in the '70s helped me a lot personally and professionally.

Do you feel stigmatised by your profession?

I proudly present myself as a psychiatrist in my country and elsewhere in the world. Not only am I not stigmatised in my country for being a psychiatrist, but I feel I have been socially rewarded for it.

\section{What are your interests outside} of work?

My family (I call them my tribe) is the pillar of my life, then reading, then (whenever possible) enjoying cultural tourism.

Who was your most influential trainer, and why?

Two people influenced my professional life in a significant way. One is Pierre Pichot, who accepted me in his department in Sainte-Anne Hospital in Paris in 1973, while I was an intern in Morocco. He has always been very supportive, and he taught me (with many others) classic French psychiatry. The other person was Norman Sartorius who, although not one of my trainers, taught me the importance of mental health.

Which publication has influenced you most?

Certainly Henri Ey's Manual of Psychiatry (1970), which attempts to combine three components of psychiatry: biological, psychodynamic and social. I would like to mention also a beautiful book by Jean Delay: Les troubles de I'humeur (1946). A masterpiece. French psychiatric literature

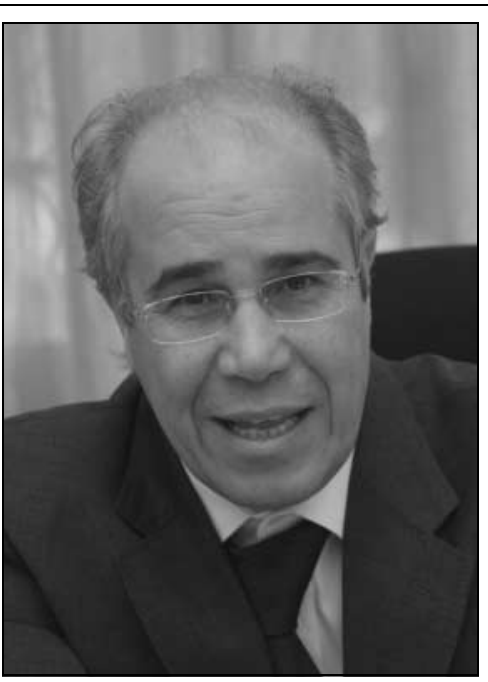

from the 19th and the early 20th century is a delight to read. More recently, papers and books written by Leon Eisenberg and Arthur Kleinman are certainly of importance for the future of psychiatry and mental health.

How has the political environment influenced your work?

Even if you don't take care of politics, it will still have an impact on you and not always in the best manner. I have been involved in many international professional groups, especiallyWHO,World Psychiatric

Association and WASP. This has brought many advantages to my department and to psychiatry in my country, and I hope that I have also contributed a little bit to the advancement of world psychiatry.

What part of your work gives you the most satisfaction?

Improving the daily life of patients. I am very touched by the affection shown by patients and families when they are well served. This kind of recognition happens more often in low- and middle-income than in highincome countries.

\section{What do you least enjoy?}

Frustration when I can't do more for the patients and their families because of a lack of resources. I also hate the hypocrisy of decision-makers who fake interest in mentally ill patients but hold stigmatising opinions about them. Because I work with the Government, each victory over Nietzsche's dragon ('on every scale of which, it is written: "you must"') is a delight.

\section{What is the most promising} opportunity facing the profession? Biological understanding of the functioning of the brain is of essence, especially neuroplasticity and neurotrophic factors. What is also extremely important to address is the gene-environment interaction. Pharmacogenetics is another opportunity. Cultural psychiatry is also coming back strongly nowadays because of the huge migratory movements worldwide.

What is the greatest threat?

The more powerful psychiatry becomes, the more responsible it should be. Ethical education and practice will be the engine that will drive psychiatry forward; without them, our specialty will sink.

What single change would substantially improve quality of care? Education of patients and families. They are our partners, our allies, the ambassadors of psychiatry. Not to help them help themselves would be an error and a tremendous waste.

What is the role of the psychiatrist in countries emerging from conflict? This is not applicable to Morocco, where, in the Saharan provinces, there has been a ceasefire with the Polisario since 1981 However, I know a number of psychiatrists who work in regions devastated by war. The psychological suffering caused by wars is huge, and psychiatrists who work (some of them even doing research) in such conditions are true heroes.

What is the most important advice you could offer to a new trainee?

To read the best psychiatric papers and books from the second half of the 19th and the first half of the 20th century, in parallel with the best current research studies. The first set educates best in phenomenology, and the second in biology and psychopharmacology.

What are the main ethical problems that psychiatrists will face in the future?

Should we present (or not) the patients with their psychiatric genetic vulnerabilities, and recommend (or not) a preventive treatment?

Do you think psychiatry is brainless or mindless?

Unfortunately both. There is not enough integration of brain and mind in psychiatry.

What single area of psychiatric practice is most in need of development?

Child and adolescent psychiatry.

What single area of psychiatric research should be given priority? High priority: perinatal psychiatry with long-term prospective studies.

How would you like to be remembered?

As one of the founders of psychiatry in Morocco and in the Maghrebian countries.

Dominic Fannon

doi: 10.1192/pb.bp.108.024299 